\title{
KÜÇÜĞÜN TIBBÎ MÜDAHALEYE RIZASI
}

\author{
Yrd.Doç. Dr.Zarife ŞENOCAK*
}

\section{GİRIŞ}

Hastanın hekim tarafından tedavisi bir hukuki ilişki çerçevesinde gerçekleştirilir. Bu hukuki ilişki genellikle bir tedavi sözleşmesidir. Tedavi sözleşmesi hekimle hasta arasındaki bir borç ilişkisi olup, edim yükümlerini ve yan yükümleri ihtiva eden, hastalık ve tedavinin türï ile paralel bir süreç arz eden bir organizma olarak da adlandırılabilir'. Özel hukuk hükümlerine tabi olan bu ilişkide irade özerkliği ilkesi egemendir.

Hekimle hasta arasındaki söz konusu hukuki ilişki, uygulamada birçok problem ortaya çıkarmaktadır. Bu problemlerin önemli bir bölümü, hekimin tıbbi müdahale için hastayı aydınlatma ve rızasını alma yükümlülügüne ilişkindir. $\mathrm{Bu}$ alandaki problemler büyük ölçüde, hekimle hasta arasındaki konum farklılığından kaynaklanmaktadır. Bir tarafta hastalığının baskısı altında bulunan, hekimin yardımına muhtaç ve tedavi sözleşmesinin konusu olan tıbbi müdahale konusunda bilgisiz hasta; diger tarafta bütün mesleki bilgi ve tecrübesiyle hekim... Hekim, bu ilişkideki mesleki rolü dolayısıyla hastanın sağlık sorunlarına ilişkin olarak karar verme yetkisine sahiptir. Bir başka deyişle, hekimlik mesleğini icrada geçerli olan "tedavi özgürlü̆ğu" ilkesi gereği, tedavi yöntemi, dolayısıyla tıbbi edimin şekli ve kapsamı hekim tarafından belirlenir. Fakat diğer taraftan hekim, kişi özgürliiklerinin bir parçası olarak kabul edilen "kendisi hakkında bizzat karar verme hakkı" nedeniyle, yapılacak her tıbbi müdahaleden önce hastanın rızasını almak zorundadır. Hastayı aydınlatma ve rızasını alma yükümlüllügüüün şekli, kapsamı ve sınırları ise, özellikle hastanın yaşam ve sağlığının kutsallığı ile irade özerkliğine, yani " kendisi hakkında kendi kendine serbestçe karar verebilme hakkına (Selbstbestimmungsrecht) saygı" ilkesinin çatıştığı durumlarda başlı başına sorun yaratmaktadır. Bir de hasta ergin değilse, yani küçükse, hekim hasta ilişkisinde bir takım ilave sorunlarla karşılaşılmaktadır. Zira bu durumda, hekim hasta ilişkisine üçüncü bir rol

* Ankara Universitesi Hukuk Fakültesi Medeni Hukuk Anabilim Dalı Ö̆rretim Oyesi

' Karş. Deutsch, E.: Medizinrecht, 3. Aufl., Berlin Heidelberg 1997, Nr.48. 
sahibi kişi olarak yasal temsilci iştirak etmektedir. Hekim, küçük ile yasal temsilci arasında bu konuda bir uyuşmazlık çıkı̆̆̆nda, hastalığın ve tedavi seçeneklerinin değerlendirilmesinde nasıl bir tutum alması gerektiği konusunda sorunlar yaşamaktadır. Bu noktada, hekimin yasal temsilcinin rızasıyla, fakat küçüğün iradesine aykırı olarak ya da tam tersine, küçügüun rızasıyla, fakat yasal temsilcinin iradesine aykırı olarak küçüğü tedavi edip edemeyeceği hususunda yoğun tartışmalar gïndeme gelmektedir.

Çalışmada esas itibarıyla, küçüğe yapılacak tıbbi müdahaleler ile ilgili özel sorunlar ele alınmış olup, hekimin aydınlatma yükümlülüğünün kapsam ve simırları ile tıbbi müdahaleye rıza hususlarında ortaya çıkan genel nitelikteki problemler mümkün olduğunca inceleme dışı tutulmuştur.

\section{Tıbbi Müdahele Kavramı}

Literatürde yapılan tanıma göre, tıbbi müdahale, "fiziksel ya da psikolojik nitelikteki hastalıkları, acıları, hastalık niteliğini taşımayan fiziksel (örneğin belli dereceye kadar şaşılık) ya da psikolojik bozuklukları, yine hastalık niteliğini taşımayan şikayetleri (örneğin, hamilelik esnasındaki şikayetler) önlemek, teşhis etmek, iyileştirmek ya da bunlarm etkisini hafifletmek amaciyla insan vücuduna yapılan tüm müdahalelerdir"'. Bu ve benzeri tanımlar zorunlu olarak "tıbbi müdahalenin tedavi amacına yönelik olması" unsurunu ihtiva etmektedir. Oysa günümüzde, rıza alınmak şartıyla, yapay dölleme, sterilizasyon, tıbbi açıdan endikasyonu olmayan kürtaj (gebeliğin onuncu haftası doluncaya kadar), başkasına nakletmek amacıyla organ ve doku alınması gibi tedavi amacını taşımayan tıbbi müdabaleler de yapılabilmektedir. Bu tip tıbbi müdahalelerde, "kişinin sağlık kazanması, iyileşmesi" yönündeki üstün bir amacın yerini, nüfus planlaması veya bir başkasının sağlık ve yaşamı gibi, hukukun korumaya değer gơrdüğu başka bir amą̧ almıştır. Bazen de, estetik ameliyatlarda ya da cinsiyet değişikliğine ilişkin tıbbi müdahalelerde olduğu gibi dolaylı bir tedavi amacı (psikolojik sağlı̆̆ı korunması ve kazandırılmasına yönelik olarak) yeterli göriulmektedir. Bunlara bir de, sayısı ve çeşitleri sürekli olarak artış gösteren teşhis koyma amaçlı invasiv müdahaleler eklenmiştir ${ }^{3}$. Tibbın bu gelişimi karşısında, bugün artık tıbbın konusunun tıp tekniğinin uygulanması haline geldiğinden söz edilmektedir ${ }^{4}$. Bu açıdan, hekimle hasta arasındaki sözleşmeyi, en azından doğrudan tedavi amacını taşımayan tıbbi

\footnotetext{
2 Voll, D.: Die Einwilligung in Arstrecht, Frankfurt am Main 1996. s. 12; Fröhlich, U.: Forschang wider Willen, Mannheim 1998, s.9; Laufs,A . / Uhlenbruck, W.: Handbach des Arztrechts, 2. Auf7., München 1999. §52, Nr.1.

Laufs/Uhlenbruck. $44, \mathrm{Nr} .1$.

4 Luts/Uhlenbruck. \$ 52, $\mathrm{Nr}, 2$.
} 
müdahaleleri konu edindiğinde, tabbi müdahale sözleşmesi ya da hekimlik sözleşmesi olarak isimlendirmek yerinde olur kanısındayız.

Tibbi müdahele kavramına bu çerçevede, cerrahi müdahaleler, anestezi, röntgen ve ışın tedavileri, şok-terapi, ultrason, ilaçla tedavi gibi az ya da çok klasik örnekler yanında; kan testleri, organ- fonksiyon testleri, koruyucu aşılar, laparoskopj, endo- rektoskopi gibi müdahaleler de dahildir ${ }^{5}$.

\section{Tıbbi Müdahaleye Rıza ve Tıbbi Müdahaleye Rızanın Tedavi Sözleşmesi ile İlişkisi}

Tedavi sözleşmesinin konusunu tıbbi müdahalenin oluşturması nedeniyle, bu sözleşme türü hastanın kişilik değerleriyle yakın ilişki içerisindedir. Hekim bu sözleșmeden doğan asli edim yükümünüi (hastanın iyileşmesi, sağlık kazanması için iş görme yuikümü) yerine getirmek için gerek teşhis, gerek tedavi aşamasında, hastanın vücut ve ruh bütünlüiơü veyahut da giz alanı gibi kişi varlıklarımı ihlal etmek zorunda kalmaktadır ${ }^{6}$. Bu nedenle tedavi sözleşmesi, genellikle sadece malvarlığına ilişkin hüküm ve sonuçlar doğuran diğer sözleşme türlerinden farklıdır. Tedavi sözleşmesinde, kişiliğin korunmasına ilişkin problemler ağır basmaktadır. Her ne kadar tedavi sözleşmesinde hastanın ücret ödeme yükümlülüğü ile hekimin hastanın iyileşmesi, sağlık kazanması yönündeki tıbbi müdahalede bulunma yükümlülï̆ğü snallagmatik ilişki içerisinde bulunmakta ise de, tedavi sözleşmesinde ağır basan menfaat, hekimin ücretin ödenmesi hususundaki menfaati değil, hastanın iyileşmesi hususundaki menfaatidir.

Hekim hasta arasındaki tedavi ilişkisinde, bir borçlar hukuku sözleşmesi olan tedavi sözleşmesi ilişkisini ve bu sözleşme dolayısıyla hastanın kişilik değerlerine müdahaleyi hukuka uygun hale getiren rıza konusunu birbirinden ayırmak gerekir ${ }^{7}$. Çoğu zaman, tıbbi müdahaleye izin verilmesi tedavi sözleşmesinin de kurulması; rızanın verilmemesi bu sözleşmenin sona erdirilmesi (BK. mad. 396 anlammda fesih) sonucunu dogurmaktaysa da, her iki kavram birbiriyle örtüşmez. Dolayısıyla tedavi sözleşmesinin kurulmuş olması, yapılacak tıbbi müdahaleye veya en azından her tıbbi muidahaleye hastanın rıza vermiş olduğu anlamına gelmez.

\footnotetext{
'Voll, s. 12-13; Fröhlich, s.9; Naegeli, M.: Die Aertzliche Behandlung handlungsunfaehiger Patienten aus zivilrechtlicher Sicht, Zürich 1984, s. 98.

6 Naegeli, s.68.

7 Naegeli, s. 69; karş. Bucher, E.: Der Persönlichkeitsschutz beim aeratlichen Handeln: Arzı und Recht, Berner Tage für die juristische Praxis 1984, Bern 1985, s. 42 (kısaltılmısıı: Bucher Persönlichkeitsschutz).
} 
Üçüncü kişi yararına yapılan tedavi sözleşmelerinde durum daha belirgindir ${ }^{8}$.

Her tıbbi müdahale hastanın kişilik haklarına yapılan hukuka aykırı bir ihlal teşkil eder. Rıza ya da diğer bir hukuka uygunluk sebebi (kamu yararı, üstün özel yarar, vekaletsiz iş görme vs.) tıbbi müdahalenin hukuka aykırılığını ortadan kaldırır". Rıza olmaksızın yapılan her tıbbi müdahale, tıp biliminin genel olarak tanınan ve kabul edilen kurallarına uygun şekilde yapıImış olsa bile, hem hastanın kişi özgürlüklerinin bir parçası olan kendisi hakkında bizzat karar verme hakkının ${ }^{10}$, hem de vücut bütünlügüünün ihlali anlamına gelir". Federal Mahkeme'nin bir kararında ${ }^{12}$ belirttiği gibi, "rıza ve hastayı aydınlatma yükümlülüğü, sadece hastanın özgür iradesinin oluşumuna değil, aynı zamanda vücut bütünlüğünün korunması amacına hizmet eder; zira burada kişiliğin korunması, hak sahibinin özgür iradesiyle vücut bütünlüğüne yapılacak herhangi bir müdahale hakkında karar verebilmesini sağlama amacını güder. Bu anlamda, tıbbi müdahalelerde kişinin özgür iradesi ve vücut bütünlü̆üü birbirinden ayrılmaz şekilde kişilik hakkının korunmasının muhtevasına dahildir".

Hekimin tıbbi müdahalesini hukuka uygun hele getiren rızanın hukuki niteliği öğretide tartışımalıdır. Türk ve Isviçre hukukunda hakim olarak gözüken görüşe göre, rıza bir hukuki işlemdir; çünkü rıza ile kişi bir hukuki

\footnotetext{
${ }^{8}$ Bkz. dpn 18 'e ilişkin metin vd.

9 Cilingiroğlu, C.: Ttbbi Müdohaleye Rtza, Istanbul 1993, s. 43; Honsell, H. / Baer, W. I Kuhn, M. /... Handbuch des Arztrechts, Zürich 1994, s.122 (kısaltılmışı: Honsell/..., Arztrecht): Voll, s.37; Özan; B.: Şahsin Hukuku, Hakiki Şahıslar, B. 7, Ankara 1997, s. 121 (kısaltılmışı: Öztan, Sahsın Hukuku); Oğuzman, K. / Seliçi, Ö. / Oktay, S.: Kişiler Hukuku (Gerçek ve Tüzel Kişiler), B. 6, Istanbul 1999, s.118; Eren, F.: Borģlar Hukuku, Genel Hükumler, C.I, B.6, Istanbul 1998, s. 587.

10 Karş. Geiser. Th.: Die Persönlichkeitsverletzung insbesondere durch Kunstwerke, Frankfurt am Main. s. 31; Gross, J.: Die Persönliche Freiheit des Patienten, Bern 1977, s. 134; Honsell/Wiegand, Arztrecht, Zürich 1994, s. 121; Kilı̧oğlu. A .: Borģlar Hukuku, Genel Hükiumler. C.I, Ankara 2001, s.171.

"Öğretideki diğer görüşe göre, hastayı gereği gibi aydınlatmadan yapılan tıbbi miudahale. sadece hastanın kendisi hakkında bizzat karar verme hakkına yapıımış bir tecavüz sayılır. Bu nedenle, hekimin ayd̛̀nlatma yükümlülügŭ çerçevesinde bỉdirmesi gereken bir rıski hastaya söylemeden nzasım alarak yaptığ tabbi müdahele sonucu, bildirmediği risk gerçekleşmiş ve örneğin hasta felç olmuşsa, bu müdaheleyi tıp biliminin tanınan ve genel kabul gören kurallarına uygun şekilde yapmış olduğu takdirde, hekim, sadece hastanın karar verme özgürlüğünü ihłal etmiş olmasından dolays manevi tazminat ödemek zorunda kalır. Buna karşllık, yukarıda belirtilen görüş kabul edildiğginde, hekim tıbbi müdaheleyi tıp biliminin genel olarak tanınan ve bilinen kuralłarına uygun şekilde yapmuş olsa dahi. hastaya manevi tazminat yanııda, biłdirmediği riskin gerçekleşmesinden dolayı (örnek bağlamında, hastanın fe!ç olmastndan dolayt), maddi tazminat da ödemek zorundadır. Bu konudaki tartışmalar için bkz. Honsell/Wiegand, Arztrecht, s. 186-187; Laufs/Uhlenbruck, \$ 67, Nr. 2 vd.: Deutsch, Nr. $167 \mathrm{vd}$.

${ }^{12} B G E 1 / 7 \mathrm{lb}$ s. 201.
} 
sonuca yönelik bir irade açıklamasında bulunmaktadır ${ }^{13}$. Buna karşılık Alman hukukunda hakim olan görüşe göre, rızanın hukuki niteliği hukuki işlem benzeri bir fiildir ${ }^{14}$. Bu görüşe göre, rıza ile kişi bir hukuki sonuca, yani tıbbi müdahalenin hukuka aykırılığını ortadan kaldırmaya yönelmemekte; fiili bir sonuca, yani tıbbi müdahalenin gerçekleştirilmesi amacına yönelik olarak hareket etmektedir. Hukuk düzeni de bu irade açıklamasına, kişinin iradesinden tamamen bağımsız olarak hukuki bir sonuç, yani hukuka aykırıh̆ğın kaldırılması sonucunu bağlamaktadır. Öğretide, hukuki işlem benzeri fijllere, hukuki işlemlerde ehliyete ilişkin kuralların kıyasen uygulanacağt kabul edildiğinden ${ }^{15}$, bu tartışmaların konumuz açısından pratik önemi yoktur. Diğer taraftan, MK mad. 16'ya göre, ayırt etme guicüne sahip küçük ya da kısıtlıların kişiye sıkı sıkıya bağlı haklarını yasal temsilcinin rızası olmaksızın tek başına kullanabileceklerini ifade etmek gerekir.

\section{Küçïłge Yapılacak Tıbbi Müdahalelerde Tedavi Sözleşmesi}

Öğretide hakim olan görüşe göre, hekim ile hasta arasındaki tıbbi müdahaleye ilişkin sözleşme, tıbbi müdahalenin konusu ne olursa olsun (cinsiyet değişikliği, sterilizasyon, kürtaj, estetik ameliyatlar ve bütün tedavi sözleşmeleri) vekalet sözleşmesi niteliğini taşı1 ${ }^{16}$.

MK mad. 16'ya göre ayırt etme gücüne sahip küçükler, karşılıksız kazanmalar ve kişiye sıkı sıkıya bağlı haklar hariç olmak üzere, yasal temsilcilerinin rızası olmadıkça kendi işlemleriyle borç altına giremezler. Tedavi sözleşmesi de bir borçlandırıcı hukuki işlem olup, bununla küçük

${ }^{13}$ Hinderling, H.: Die Aerztliche Aufklaerungspflicht: Ausgewaehlte Schriften, Zürich 1982, s.72; Jaeggi, P.: Fragen des privatrechtichen Schutzes der Persönlichkeit, ZSR NF $1960 \mathrm{II}$, 205a vd.; Von Tuhr, A J Peter, H.: Allgemeiner Teil des Schweizerischen Obligationenrechts, Bd.I, 3. Aufl., Zürich 1979; s. 419; Kilı̧̧oğlu. A.: Şeref. Haysiyet ve Özel Yaşama Bastn Yoluyla Saldirtardan Hukuksal Sorumluluk, B.2, Ankara 1993, s. 176; Eren, C.I, s.587; Oğuzman, M. K. IÖz, M.T. Borçlar Hukuku, Genel Hakümier, B.2. Istanbul 1998, s.482.

${ }_{14}$ Palandt, O.: Bürgerliches Gesetzbuch, 58. Aufl., München 1999, Uberbl vor $\$ 104, \mathrm{Nr} .6$; Alman hukukunda bu konuya ilişkin ayrıntılı bilgi için ayrıca bkz. Mayer, $K$. $G$.: Medizinische Massnahmen an Betreuten, Würzburg 1995, s. 26 vd. ; Türk hukukunda ayn görüşte, Sarial, E.: Sağlararast Organ Nakillerinden Dơgan Hukuksal Ilişkiler, Istanbul 1986, s. 64-65; Çilingiroğlu, s. 44.

is Eren, C.I, B.6. Istanbul 1998, s. 155; Tekinay, S. S. / Akman, S. / Burcuoglu, H. / Altop, A .: Tekinay Borçlar Hukuku, Genel Hükümler, B.7. Istanbul 1993, s.39.

${ }_{16}$ Bu konuda ayrıntılı bilgi jçin bkz. Ayan, M.: Tıbbi Müdahelelerden Doğan Hukuki Sorumluluk, Ankara 199J, s.53 vd.; Şenocak, Z.: Özel Hukukta Hekimin Sorumluluğu, Yükses Lisans Tezi, Ankara 1998 , s. 24 vd. Sterilizasyon, kürtaj, estetik ameliyat gibj tıbbi müdahelelerde de, sonucun ortaya çıkmasının hekimin tamamen hakim olmadı̆̆ faktörlere bağlı olması nedeniyle, hekimin sonucu değil, sonucun ortaya çıkması için tıp biliminin kurallarına uygun bir iş görmeyi borçlandığından hareketle, bir eser sözleşmesinin söz konusu olmadığı kabul edilmektedir. Ayrıntılı bilgi için bkz. Laufs/Uhlenbruck, $\$ 39, \mathrm{Nr} .16$ vd. 
hekime ücret ödeme borcu altına gireceğinden, ayırt etme gücüne sahip küçüğün bu sözleşmeyi (kendi ad ve hesabına) yapabilmesi için yasal temsilcinin (izin veya icazet şeklinde) rızasına ihtiyaç vardır. Aksi takdirde yapılan sözleşme geçersizdir.

Bunınla beraber, kü̧̧ügüin kendi kazancının olması durumunda, tedavi sözleşmesini yasal temsilcisinin rızası olmaksızın yapabilip yapamayacağı ayrıca değerlendirilmesi gereken bir husustur. MK mad. 359/II, ana babanın çocuğun mallarının bir bölümünü bağımsız bir meslek ya da sanatla uğraşması için ona vermesi durumunda, meslek ve sanatm gerektirdiği işlemlerle sınırł olmak üzere; yine çocuğun kendi çalışmasımın ürünü olan kazancı üzerinde, kazanç miktarı ile sınırlı olmak üzere küçüŭüün tam fiil ehliyetine sahip olacağını belirtmektedir. Bu çerçevede ayırt etme gücüne sahip küçük, tıbbi müdahale iş gücünün muhafazasına ya da yeniden kazanılması amacına hizmet ettiği veya kişisel kazancı ile sınırlı olduğu sürece, sağlığı için gerekli olan tedavi sözleşmelerini ana babanın rızası olmadan yapabilmelidir ${ }^{17}$.

Küçuị̂e yapılacak tıbbi müdahaleler için uygulamada tedavi sözleşmesini genellikle ana baba yapmaktadır. Ana baba (evlitik birliği içinde) küçuiğüun tedavisi için birlikte hekime başvurduklarında, sözleşme ana baba ve hekim arasında meydana gelir; başika bir deyişle sözleşmenin tarafları ana baba ve hekimdir ${ }^{1 \mathrm{x}}$. Ana ve babadan her biri çocuğu tek başlarma hekime götürdüklerinde de durum böyledir: zira MK mad. 188/I'e göre eşlerden her biri, ortak yaşamın devamı süresince ailenin sürekli ihtiyaç̧arı için evlitik birliğini temsil etme yetkisine sahiptir. MK mad. $189^{\circ}$ a göre ise, birliği temsil yetkisinin kullanıldığı hallerde eşler üz̧üncü kişilere karş̧ı müteselsilen sorumlu olurlar. Çocư̆un bakımı, dolayısıyla sağ̣tı̆ııın korunması da ailenin sürekli ihtiyaçlarına dahil olduğundan ${ }^{19}$, ana babanın her biri çocuk için bir tedavi sözleşmesi yaptığında, bu sözleşme evlilik birliğini temsilen yapılmış sayılı ${ }^{20}$. Dolayısıyla diğer eş de sözleşmenin tarafı olur.

Buna karşılık tıbbi açıldan zorunlu olmayan pahalı tıbbi müdahalelerde (örneğin porselen diş yaptırılması, sosyal sigortanın varlığına rağmen özel

\footnotetext{
17 Karş. Laufst Uhlentruck. § 40. Nr. 17; Honsell, H. / Vogt, N. P. / Geiser, Th.: Schweizerisches Zivilgesetzbuch I. Art. 1-359 ZGB, Basel 1996, Ar 323, Nr. 4 (kısaltılmı̧l: Honsell/...).

${ }^{18}$ Lauffs/Whienbruck. \$40, Nr. 17; Naegeti, s. 80. Üçüncü kişi (küçük) yararına sözleşme olarak nitelendirilen bu tedavi sözleşmesinde, ana babanır bu suretle çocuğa yaptı̆̆ı kazandırmanın temelinde, MK mad. 327 vd. hükümlerinde düzenlenmiş bulunan ana babanın çocuğa bakım yükümlülü̆ğgi yatmaktadır.

${ }^{19}$ Honsell/hasenbohler, Art. 166. Nr.7.

${ }^{3}$ Latfsl/Uhtentruck, \& 40. Nr. 21; kars. Natgeli, s. 81-82.
} 
hekime başvurulması, pahalı bir gözlïğün 1smarlanması durumlarında) hekim diğer eşin de rızasımı almahıdır ${ }^{21}$. Aksi takdirde, böyle bir sözleşme ile sadece sözleşmeyi yapan ana ya da baba borç altına girer ${ }^{22}$.

Ortak hayata son verildiğinde veya ayrılık halinde (bu durumlarda geçici olarak) ya da evlilik boşanma kararı ile sona erdiğinde eşlerin evlilik birliğini temsil yetkisi sona erer ${ }^{23}$. Dolayısıyla, velayet kendisine bırakılan ya da (ortak hayata son verilmesi veya ayrılık halinde MK mad. 336/II'ye göre eşlerden her ikisinin de velayet hakkına sahip olması durumunda) ${ }^{24}$ çocuk kendisine bırakılan taraf hekimle tedavi sözleşmesini yapar. Diğer eş, çocuğa karşı bakım yükümlülügüünü mahkemenin tespit edeceği nafaka ile (iştirak nafakası) yerine getirir. Aynı durum ana babanın evli olmaması durumunda, çocuğun soybağımın babaya karşı babalığa hüküm (MK mad. 301) ya da tanıma yoluyla (MK mad. 295) kurulması halinde de geçerlidir. $\mathrm{Bu}$ durumda da sözleşmenin tarafı, kural olarak, MK mad. 337'ye göre velayet hakkma sahip olan taraftır ${ }^{25}$.

Ana ve babanın (veya sadece ana veya babanın) hekimle yaptığı tedavi sözleşmesi (vekalet sözleşmesi) ögretide hakim olan görüşe göre, ïçüncü kişi lehine (yani çocuk lehine) sözleşmedir ${ }^{26}$. Eğer çocuk ayırt etme gücüne sahip değilse, ana babanın çocuğa, tedavi sözleşmesinden doğan borcun ifasını hekimden talep hakkını tanımak istemediklerinden hareketle, burada eksik üçünciü kişi yararına sözleşmenin varlığı kabul edilmektedir ${ }^{27}$. Bu durumda, ifanın (tıp biliminin kurallarına uygun tıbbi müdahalenin) çocuğa yapılmasını talep hakkı ana babaya ait olup, çocuk borçlanılan edimin lehdarı, yani yapılacak ifanın muhatabı konumundadır ${ }^{28}$. Tedavi

${ }^{21}$ Laufs/Uhlenbruck, $\$ 40, \mathrm{Nr} .23$.

${ }^{n}$ Bu tıbbi müdaheleler, ailenin sürekli ihtiyaçları dışında kaldığından, MK mad. 188/II'nin kapsamuna girer. MK mad. 188/II'ye göre:

"Ailenin diğer ihtiyaçlan için eşlerden biri, ancak aşağıdaki hallerde temsil edilebilir:

1. Diğer eş veya haklt sebeplerle hakim tarafindan yetkili kilmmşsa.

2. Birliğin yararı bakımmdan gecikmede sakmca bulunur ve diğer eşin hastalı̆̆ı, başka bir yerde olmasi veya benzeri sebeplerle rizası almamazsa".

${ }_{23}$ Honsellihasenböhler, Art. 166. Nr. 22; Naegeli, s. 83.

${ }^{24}$ Bize göre, MK mad.336/II "Ortak hayata son veritmiş veya ayrılık hali gerçekleşmişse hakim, velayeti eşlerden birine verebilir." hükmünün yorumu, velayet hakkımın her iki eşe birlikte bırakılabileceğ şeklinde yapılmalıdır. Nitekim, kaynak Kanun'un $297^{\prime}$ nci maddesinin yorumu da bu şekildedir. Bkz. Honsell/Schwenzer, Art. 297, Nr, 10.

${ }^{25}$ MK'nun 337 'nci maddesine göre "Ana ve baba evli değilse velayer anaya aittir. Ana kü̧̧ü. kısıth veya ölmüs ya da velayet kendisinden alınnuşsa hakim, çocuğun menfaatine göre, vasi atar veya velayeti babaya verir."

${ }_{20}$ Krauskopf, P.: Der Vertrag zugunsten Dritter, Freiburg 2000, Nr. 8; Naegeli, s. 80; Laufs/Uhlenbruck, \$ 40, Nr.24; karş. Serozan, R.: Cocuk Hukuku, Jstanbul 2000, Nr. 255.

${ }^{27}$ Laufs/Uhienbruck, $\$ 40, \mathrm{Nr} .25$.

2. Eren. F.: Borçlar Hukuku, Genel Hükumiler, C.II, B.2, Istanbul 1998, s. 1133 ; Oğแzman/Öz. s.791. 
sözleşmesinden doğan alacak hakkı ana babaya ait olduğu gibi, hekime ödenecek ücretin borçlusu da sözleşmenin tarafı olan ana babadır ${ }^{29}$. Bununla beraber, tedavi sözleşmesinin hiç veya gereği gibi yerine getirilmemesi sonucu zarara uğrayan çocuğun, şartları varsa BK mad. 41 vd.'na dayalı olarak hekimden tazminat talep etme hakkı söz konusudur ${ }^{30}$.

Buna karşılık, çocuğun ayırt etme gücüne sahip olması durumunda, tıbbi müdahaleye rıza gösterecek kişinin kendisi olmasından hareketle, öğretide, ana baba ve hekim arasınđa tam uiçüncü kişi yararına sözleşmenin varlığ 1 kabul edilmektedir ${ }^{31}$. Bu durumda, ana baba sözleşmenin taraf 1 sıfatını devam ettirmekle beraber, çocuk bu sözleşmeden doğan bir alacak hakkına sahip olup, hekimden borcun ifasını; borç hiç veya gereği gibi yerine getirilmediğinde ise, bu suretle meydana gelen zararın tazminini talep edebilir. Bunun yanında, ana baba da tedavi sözleşmesinden doğan edimin çocuğa ifasını isteyebilir ${ }^{32}$. Öğretide ileri sürülen bir görüşe göre. vaadettiren (konumuzla bağlantılı olarak ana baba), sözleşmenin ihlali halinde ortaya çıkan tazminat borcuna ilişkin olarak da, içüncu kişiye (konumuz bağlamında çocuğa) ifayı vaadedenden (borçludan- konumuz bağlammnda hekimden) talep hakkına sahiptir ${ }^{33}$; örneģin çocuk yararına yapilan bir tedavi sözleşmesinin ifası sürecinde, çocuk hekimin kusuru nedeniyle felç olmuşsa, çocuk zararının tazminini hekimden talep edebileceği gibi, ana baba da bu tazminat borcunun çocuğa ifasını talep edebilit ${ }^{34}$. Ana baba, bunun yanında, çocuk yararına edimin ihlali dolayısıyla kendilerinin uğradığı zarar için de (örnek bağlamında, çocuğun bakım ve eğitim masraflarının felç olması nedeniyle artması sonucu, bu bakım ve eğitim masraflarımun normal miktarı aşan kısmı için ) hekime karşı tazminat talebinde bulunabilir. Hekimle yapılan tedavi sözleşmesini bir bütün olarak etkileyen, değiştiren veya sona erdiren yenilik dogurucu haklar, örneğin BK mad. 396 çerçevesinde sözleşmeyi feshetme hakkı ise, sadece ana babaya aittir $^{35}$.

\section{Küçüğün Tıbbi Müdahaleye Rızası}

Medeni Kanun'un 16'ncı maddesine göre, ayırt etme gücüne sahip küçükler, kişiye sıkı sıkıya bağlı haklan yasal temsilcilerinin rızasına ihtiyaç

\footnotetext{
29 Naegeli.s. 80.

Karş. Krauskopf, Nr. 812 vd.

${ }^{31}$ Laufs/Uhienbruck. $\$ 40, \mathrm{Nr} .25$.

32 Karş. Eren, C.II, s. 1138; Akyol, Ş.Tam Ü Ģüncï Şahı Yararma Sözleşme. Istanbul 1976,

s. $110 ; O \not g u z m a n / O ̈ z, s .801$

${ }^{33}$ Krauskopf. Nr. 1375.

${ }^{34}$ Karş. Krauskopf. $\mathrm{Nr}, 1576$.

35 Krauskopf, Nr. 1048, Nr. 1386; Eren. C.11, s. 1137.
} 
olmaksızın kullanabilirler ${ }^{36}$. Bu hüküm, ayırt etme gücüne sahip küçüklerin, kişiye sıkı sıkıya bağlı hakların kullanılması bakımından, tam ehliyetli olduğu anlamına gelmektedir ${ }^{37}$. Söz konusu maddede, bu hakların neler olduğu belirtilmemiştir. Bu kural içi boşluğun doldurulması, pozitif hukuktaki özel huikümlerle ve öğreti ile yargı içtihatlarnnca sağlanmaktadır ${ }^{38}$.

Bu haklar esas itibarıyla temsil yoluyla kullanılmaya elverişli değildir. Bununla beraber, ögreti ve uygulama, kişiye sıkı sıkıya bağlı hakların kullanılmasında söz konusu olan temsil düşmanlı̆ının, ayırt etme gücüne sahip olmayan kişilerin bu haklarını kullanamaması ve bu alanda bir anlamda hak ehliyetlerinin kalkması sonucuna yol açtığını da göz ardı etmemektedir. Bu kaygı ile, mutlak anlamda kişiye sıkı sıkıya bağlı haklar ve nisbi anlamda kişiye sıkı sıkıya bağlı haklar tasnifi yapılmaktadı ${ }^{39}$.

Mutlak anlamda kişiye sıkı sıkıya bağlı hakların, hak sahibi tarafından bizzat kullanılması gerekmektedir [Örneğin, nişanın bozulması (MK mad. 119) ve manevi tazminat talebi (MK mad. 121), mirasbırakan stfatıla miras sözleşmesi yapma (MK mad. 503) vs. ]. Bu da, mutlak anlamda kişiye sıkı sıkıya bağlı hakların ayırt etme gücüne sahip olmayan küçükler ve kısıtlılar tarafından kullanmasını imkansızlaştırmaktadır. Buna karşılık nisbi anlamda kişiye sıkı sıkı bağlı haklar, ayırt etme gücüne sahip olmama durumunda temsili caiz kılmaktadır; bu hakları kişi ayırt etme gücüne sahipse bizzat kullanabilmekte, ayırt etme gücüne sahip değilse bunlar yasal temsilci tarafından kullanılabilmektedir ${ }^{40}$. Uygulama ve ögretinin nisbi anlamda kişiye sıkı sıkıya bağlı hak olarak nitelendirdiği haklardan biri de, kişilik degerlerinden olan vïcut ve ruh bütünlüğgi üzerinde tasarruf anlamına gelen tıbbi müdahaleye ruzadır ${ }^{41}$. Böyle bir tasnif neticesinde, ayırt etme gücüne sahip olmayan küçïğe yapılacak tıbbı müdahaleye rızanın herhangi bir teorik tartışmaya yol açmadan yasal temsilcisi tarafından verilmesi mümkün olmaktadir.

MK mad. 16 'da, kişiye sıkı sıkıya bağlı hakları ayırt etme gücủne sahip küçügüün bizzat kullanabileceği hükme bağlanmış olmasına rağmen, ayırt

\footnotetext{
36 Özıan, Şahısın Hukuku, s. 101; Zevkliler, A.+ Medeni Hukuk, B.6, Ankara 2000, s. 287; Hatemi, H.: Kişiler Hukuku Dersieri, B.2, Istanbul 2001, Nr. 173

37 Bucher, E.: Berner Kommentar, Kommentar zum schweizerischen Privatrecht. Das Personenrecht, 2. Abt., 1. Teilband, Bern 1976. Art. 19, Nr. 189.

${ }^{38}$ Bucher, Art. 19. Nr. 193; Öztan. \$ahsın Hukuku, s. 102.

${ }^{39}$ Honsell/ Bigler-Eggenberger, Art. 19, Nr. 36; Ötant, Şahsın Hukuku, s. 102.

*H Honsell/ Bigler-Eggenberger, Art. 19, Nr. 37. Bunun yanında, ayırt etme güicủne sahip küçük tarafından kullanılmakla birlikte, yasal temsilcinin de izin, icazet veya oluruyla işleme katılması gerektiği bazı kişiye sıkı sıktya bağlı haklar da, nisbi anlamda kişiye sıkı sıkıya bağhı haklarnn kapsamına sokulmaktadır. Bkz. Oğuzman/Seliçi/Oktay, s. 75-76.

4I Honsell/ Bigler-Eggenberger, Art. 19, $\mathrm{Nr}, 41$.
} 
etme gücüne sahip küçüğe yapılacak tıbbi müdahaleye nza konusu öğretide tartışmalıdır. Bu hususta ortaya çıkan görüşleri üç ana bağlıkta toplamak mümkündür: Tıbbi müdahale için yasal temsilcinin rızasını şart koşmakla beraber, ayırt etme gücüne sahip kiuçüğtin görüşünün almması gerektiğini savunan görüş; yasal temsilcinin ve ayırt etme gücüne sahip küçügüun tızasını birlikte arayan görüş ve nihayet ayırt etme gücüne sahip küçügüun rızasını tek başına yeterli sayan görüş.

Birinci görüşün yasal dayanăğını TŞSTİK'nun ${ }^{42} 70^{\prime}$ inci maddesi ve HHY'nin ${ }^{4.3} 24^{\prime}$ 'üncü ve $26^{\prime}$ incı maddeleri oluşturmaktadır. T\$SSTIK'nun 70 'inci maddesi ve HHY'nin 24'üncü maddesinin l'inci fıkrasina göre, hasta küçük veya kısıtlı ise yasal temsilcisinden izin alınır. HHY'nin 26'ncı maddesine göre ise, yasal temsilcinin rızasının gerektiği ve yeterli olduğu hallerde dahi, mümkün olduğu ölçüde küçük veya kısıtli olan hastanın dinlenmesi suretiyle tıbbi müdahaleye iştiraki sağlanır. Söz konusu hükümler lafzı ile bağlı kalınarak birlikte dikkate alındığında, ayırt etme guicüne sahip olsun olmasın, küçüğe tıbbi müdahale yapılabilmesi için esas itibarıyla yasal temsilcisinin rızasının bulunması şartının arandığı ve fakat küçüğgin de bu husustaki görüşünün alınması gerektiği anlaşılmaktadır. Küçư̆guùn görüşünün alınması, -ayırt etme gücüne sahip olsa da- bu görüşün hekim için bağlayıcı olmadı̆̆ı anlamına gelir; bu konuda son sözü söyleyecek olan yasal temsilcidir ${ }^{44}$.

Bu hukuki düzenleme, tıbbi müdahaleye rızanın kişiye sıkı sıkıya bağlı hak olduğunu ve MK'nun 16'ncı maddesinin bu husustaki dizenlemesini göz ardı etmektedir. Ö Gretinin Anayasa'nm 17'nci maddesinden ve MK'nun 24 'üncü maddesinden türettiğg ${ }^{15}$ kendisi hakkında bizzat karar verme (Selbstbestimmung) hakkını, kişiye sıkı sıkıya bağlı haklar söz konusu olduğunda MK'nun 16'ncı maddesi gereği ayırt etme gücüne sahip küçükler de kullanabilmektedir. Ayırt etme gücüne sahip küçüklere kişiye sıkı sıkıya bağlı hakiar alanında tam fiil ehliyetinin tanımmasımın sebeplerinin başında, kişiliği yakından ilgilendiren işlerde bireye bizzat karar verme, bu kararın sorumluluğunu taşıma ve de kendi kendini koruma özgürlüğünün

+ะ 1219 sayılı Tababet ve Şuabatı San'atlarını Tarzı Icrasına Dair Kanun.

${ }^{+3}$ Hasta Hakları Yönetmeliği.

+ Dural. M.: Landesbericht Turkei: Zivilrechiche Regelungen zur Absicherung der Paichtenuutonomi am Ende des Lebens, Hrsg. : Taupitz, J., Mannheim 2000, s.955.

4. Ögretide, kişinitı kendisi hakkında bizzat karar verme hakkı, Anayasa'nın 17 'nci maddesinde yer alan "yaşama ve vücut bütünlüğ̈u hakkı ile, maddi ve mancvi varlığıns geliştirme hakkındañ" ve kişiliğin haksız fiil sonucu ihlal edilmesine karșı korunmasını düzenleyen MK mad. 24'den çlkanlmaktadır.Bkz. Össunay, E.: Alman ve Tïrk Hukuklarında Hekimin Hastayı Aydutatma Ödevi ve Istisnalar: Türk Hukukında Hekimin Hukuki ve Cezai Sortmluliğu. Sorimluluk Hukukundaki Gelişmeler V. Sempozyumu, Ankura 12-13 Mari 1982, Istanbul 1983. s. 34-35; Şenocak, s. 36-37; Honsell/Wiegand, Arztrecht. s.121. 
bahsedilmesinin gerekliliği düşüncesi gelmektedir ${ }^{46}$. Diğer sebep ise, kişiye sıkı sıkıya bağlı haklar sahasında verilen kararların rasyonel sebeplerden çok, ilgilinin kişilik yapısına dayanmasıdır ${ }^{47}$. Tıbbi müdahaleye rıza da kişilik değeri olan vücut ve ruh bütünlïğ̈i üzerinde tasarruf anlamına geldiğinden, hak sahibinin kişiliği ile sıkı bir bağlantı içerisindedir ve vücut ve sağıtk üzerinde kişinin yaşam ve geleceğini ilgilendiren (özellikle önemli tıbbi müdahalelerde) önemli etkilere sahiptir. Kuçüik bu alanda tıbbi muidahalenin objesi değil, süjesi olmak zorundadı4 ${ }^{48}$. Bu nedenle küçüğüun ayırt etme gücüne sahip olmasına rağmen tıbbi müdahaleye rizanın, tamamen onun yasal temsilcisinin tasarrufuna bırakılması düşünülemez. Zaten Medeni Kanun hükümlerine bakıldığında, nisbi anlamda kişiye sıkı sıkıya bağlı hak olarak da adlandırılan bazı kişiye stkı sıkıya bağlı hakların kullanımının, küçük ayırt etme gücüne sahipse tamamen yasal temsilciye bırakılmadı̆̆ı, küçüğün iradesinin yanında yasal temsilcinin izin, icazet ya da olurunu bildirmesi şeklinde işleme katılmasının şart koşulduğu görülmektedir [örneğin, nişanlanma (MK mad. 188/II), evlenme (MK mad. 126, yargisal erginlik talebi (MK mad. 12) vs. $]^{49}$.

Küçüğe yapılacak tıbbi müdahale için, -kişiye sıkı sıkıya bağh bir hak olmasına rağmen- kïçüğün rızası yanında yasal temsilcinin rızasının aranması gerektiğini savunan ikinci görüşüun ${ }^{50}$ temelinde ise, küçüğüun korunması düşüncesi yatmaktadır. Hinderling'e göre, "kişiye sıkı sıkıya bağlı haklarda, bu hakkın ilişkin olduğu kişilik değerinin türüne göre, karar verme özgürlügüi ve sınırl ehliyetsizi koruma ihtiyacı arasındaki denge de ģişebilir. Vücut bütünlüğgünü ilgilendiren ve özel riskler içeren, özellikle uzun süre hastahanede kalmayı gerektiren tıbbi müdahalelerde ayırt etme gücüne sahip küçiıłoün rızası yanında, yasal temsilcinin de rızası aranmalıdır. Ameliyat gibi küçügŭn yaşam ve ölümünün söz konusu olduğu durumlarda, ana babaya söz hakkı tanınmaması düşünülemez"sI. Bu görüşün haklılık derecesinin değerlendirebilmesi açısından tartışılması gereken husus, tıbbi müdahalelerde ayırt etme gücüne sahip küçüğün rızası yanında onun yasal temsilcisinin de rızasının alınmasına, küçiı̆̆ün korunması açısından ihtiyaç olup olmadığıdır.

Tibbi müdahaleye ruza konusundaki ayırt etme giicii, somut olaydaki tıbbi müdahalenin önemi ve kapsamını değerlendirebilmek için gerekli

\footnotetext{
46 Bucher. Art. 19, Nr. 190.

${ }^{47}$ Bucher, Art. 19, Nr. 191.

48 Wölk, Fl:: Der minderjaehrige Patient in der aerztlichen Behandlung, MedR 2001, H.2. s.83.

49 Bkz. dpn. 40 .

5i Hinderling, s. 73; Jaeggi, s. 155a; Zevkiler. Medeni Hukuk, s. 438; Serozan. Nr. 78; önemli tıbbi müdahaleler açısından aynı görüşte Çilingiroğlu. s.56.

${ }^{51}$ Hinderling, s. 73.
} 
ruhsal ve ahlaki olgunluğa sahip olmayı ifade eder ${ }^{52}$. Kanımızca, bir kez küiçïğïn somut olayda tıbbi müdahaleye rıza konusunda ayırt etme gücünün varlığını ve dolayısıyla, kişilik değeri olan vücut ve ruh bütünlı̈ı̆̆ü üzerinde karar verme özgürlü̧üunii kullanabileceğini kabul ettikten sonra, bu hakkın kullanımın küçiugüün korunması amacıyla yasal temsilcisinin rızasına bağlı tutmak gereksiz bir tedbirdir. MK'nun 339'uncu maddesine göre, ana babanın, çocuğun bakım ve eğitimi konusunda bir taraftan onun menfaatini göz önünde tutarak gerekli kararları alıp uygulamaları; diğer taraftan olgunluğu ölçüsünde çocuğa hayatını düzenleme olanağı tanımaları ve önemli konularda olabildiğince onun düşincesini göz önünde tutmaları gerekir. Bu hükmüin amacı, ana babanın bu suretle çocuğun hak ve özgürlüklerini algılayabilmesi ve kullanabilmesi için onun kendi bağımsız kişiliğinin gelişimini sağlamalarıdır. Velayetin asıl işlevi de budur. Öğretide ifade edildiği gibi ${ }^{53}$, bu işlev aynı zamanda velayetin kapsamını ve sınırlarını belirler. Velayetin bu esnek kapsamı çocuk olgunlaştıkça daralır. Velayetin esnek kapsamını daraltan durumlardan biri de tıbbi müdahaleye razı olup olmama hususundaki karar verme özgürlügüüdür. Çocuk ayırt etme gücüne, yani tıbbi müdahalenin önem ve kapsamın değerlendirecek ruhsal ve ahlaki olgunluğa sahip olduğunda, ana babanın velayet hakkı geri çekilmeli; küçük kişiliğine sıkı sıkıya bağlı olan bu hakkını tek başına kullanabilmelidir ${ }^{54}$. Ayırt etme güciine sahip küçüklerin ana babanın rızasına ihtiyaç olmadan kişiye sıkı skkıya bağlı haklarını kullanabileceklerini öngören MK mad.

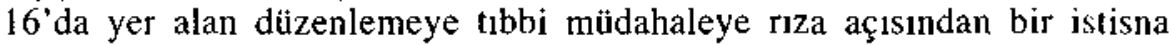
getirilmemelidir.

Diğer taraftan bir hekim tarafindan önerilen tedaviye rıza hususunda küçügüü özel bir korunmaya ihtiyacı yoktur. Küçüğün karar verme özgürlügü ve onu koruma ihtiyacı arasındaki denge, tedaviyi öneren ve uygulayacak olanın, mesleki bilgisi ile donanıml ve tıp biliminin bilinen ve genel kabul gören kurallarına göre hareket etmekle yükümlü bir hekim olması karşısında zaten mevcuttur. Öğretide, tıbbi müdahaleyi yapacak olan hekimin seçimine ve tedavi için diğer hekimlere başvurulmasının gerekip gerekmeyeceğine ilişkin problemlerde küçü̈ğün korunması ihtiyacının ağır bastığından hareketle, yasal temsilcinin rızasının gerekli olduğu görüşüi ${ }^{59}$ ileri sürülmekteyse de, bu görüşün taşıdığı endişe yersizdir. Daha önce de belirtildiği gibi, ayırt etme gücüne sahip küiçüğün tıbbi müdahaleye rıza vermeye ehil olması, onun tek başına, yasal temsilcisinin rızası olmaksızm

\footnotetext{
${ }^{52}$ Naegeli, s. 101; Wolk, s.81.

${ }^{33}$ Serozan. Nr. 240; Honsell/Schwenzer, Art.301, Nr.3.

${ }^{5}$ Bu hakkın yasal temsilcinin rızasına ihtiyaç olmaksızın kullanılabileceği görüşünde, Ö̆tan. Şahsin Hukuku, s. 103; Naegeli, s. 101 vd; Wolk, s. 89; Ramer, P./Rennhard. J.: Patientenrecht, 2. Auft, Zürich 1998. s. 50-51; Honsell/Wiegand. Arztrecht, s. 157-158; Bucher, Persönliclıkeitsschucz, s,43.

${ }^{55}$ Hinderling.s. 73.
} 
borç doğuran bir sözleşme olan tedavi sözleşmesini de yapabileceği anlamına gelmez. Tedavi sözleşmesini, ya ana baba (veya velayet hakkına sahip ana veya baba) üçúncu kişi (küçủk) lehine sozzleşme şeklinde bizzat sözleşmenin tarafı olarak yapar, ya da ayırt etme gücüne sahip küçügüun bizzat sözleşmenin tarafi olarak yapacağı veya yaptı̆̆ tedavi sözleşmesine yasal temsilci sıfatıyla izin veya icazet verir. Tedavi sözleşmesinin tarafi olacak veya tıbbi müdahaleyi yapacak olan hekimi ise aynı sözleşmenin diğer tarafi belirler. Bu kişi ya ana baba ya da küçüktür. Dolayısıyla, ana baba, sözleşmenin tarafı olarak veya sözleşme tarafının çocuk olması durumunda yasal temsilci sıfatıyla çocuğun yararı ölçüsünde sözleşmeye izin ve icazetini vermeme suretiyle tedaviyi yapacak hekimin belirlenmesinde söz sahibidir. Tedavi sürecinde başka hekimlere başvurmak gerektiğinde ise, ana baba üçüncỉ kişi lehine sözleşmede hekime BK mad. 389 çerçevesinde talimat verme veya mad. 396 çerçevesinde tedavi sözleşmesini sona erdirme hakkına sahip olduğundan bu konuda söz söyleme hakkını kaybetmemektedir ${ }^{56}$.

Küçüğün ayırt etme gücüne sahip olup olmadığını tespit etmesi gereken kişi, bizzat tedaviyi yapacak olan hekimdir ${ }^{57}$. Zira hekim, hasta hekim ilişkisi sebebiyle küçükle yakın ilişki içerisinde olup, değerlendirmeyi tedavi ilişkisine yabancı diğer hekimlerden daha iyi yapabilecek konumdadır. Bununla beraber, hekimin küçüğün ayırt etme gücüne sahip olmadığı iddiasıyla gündeme gelebilecek sorumluluk riskine karşı, (özellikle bir tedavi sözleşmesine dayanmayan, sosyal sağlık sigortasına istinaden kamu hastahanelerinde yapulacak olan) onemli ameliyatlarda yasal temsilcinin rızasını alması tavsiye olunabilir ${ }^{58}$. Yasal temsilcinin rıza vermekten kaçınması durumunda ise, tıbbi müdahale zorunlu değil ve ertelenebilir nitelikte ise, bekimin daha ayrıntrlı bir inceleme yapması ve gerekirse bu hususta uzman bir psikiyatristin yardımını alması yerinde olur; küçiı̆gün ayırt etme gücünün olup olmadığı kuşkulu olduğu takdirde ise, durum açıklığa kavuşuncaya kadar tıbbi müdahaleyi ertelemekten başka yapacağı bir şey yoktur ${ }^{59}$. Buna karşılık, küçüüün yaşam ve sağlığını tehdit eden bir tehlikenin bulunması, yani tıbbi müdahalenin acil olması durumunda, hekim tarafından yapılacak tıbbi müdahalenin hukuka uygunluk sebebini, küçüĭgün uistün yararı oluşturur ve burada vekaletsiz iş görmeye ilişkin kurallar

\footnotetext{
${ }^{56}$ Buna karşılık, ana babanın tedavi sözleşmesini yapmaktan veya ayırt etme gücüne sahip küçüğün yapacă̆ veya yaptı̆̆ı tedavi sözleşmesine izin veya icazet vermekten kaçınarak çocuğun sağlığı için gerekli olan tıbbi müdaheleyi engellediği durumlarda, mahkemeye başvurularak MK mad. 346 vd. hükiłmleri çerçevesinde kiłçủk lehine koruyucu tedbirlerin alınması sağlantlabilit (karş. HHY mad. 24/II).

${ }^{57}$ Wolk, s.86; Naegeli. s. 103.

${ }^{58}$ Halihazırda TŞSTIK' nun 70'inci maddesine göre, kúçüklere yapılacak tıbbi müdahalelerde yasal temsilcinin rızası şart olduğu gibi, büyük cerrahi ameliyatlar için bu rızanın yazılı olması da şarttır.

\$9 Aynı görüşte Naegeli, s. 125 .
} 
uygulanır. ${ }^{60}$ Acil durumlarda tıbbi müdahale bizzat kïçük tarafından reddolunduğu takdirde, böyle bir beyan hukuka aykın olduğundan, hekim küçügüun iradesi hilafına tıbbi miidahalede bulunabilir ${ }^{61}$. Öğretide, burada esas itibarıyla küçügün ayırt etme gücünün yokluğundan hareket edilebileceği de ifade edilmektedir ${ }^{62}$. Tıbbi açıdan zorunlu olmayan tıbbi müdahaleyi reddettiğinde ise, onun tabii iradesi yeterli sayılmalıdır ${ }^{6.3}$.

Hekimin küçüğün ayırt etme gücünün olup olmadığında değerlendirmesi gereken husus, onun sağlık sorunlarında kendi menfaatini gözetip gözetemediğidir. Bu bağlamda, onun, aydınlatma yükümlülüğüu çerçevesinde verilen bilgileri anlayıp anlamadığı, bu bilgileri kendi değer anlayış açısından değerlendirip değerlendiremediği ve davranışının edindiği kanaate göre belirleyip belirleyemediği hususları önem kazanır ${ }^{64}$. Tıbbi müdahaleye rızayı verecek olan ayırt etme gücüne sahip küçük oldugunndan, tıbbi müdahaJe konusunda aydınlatma yükümlülüğü de küçüğe karşı yerine getirilmelidir $^{65}$. T1bbi aydınlatma, hastaya hastalığının durumu ve gidişatı, tavsiye edilen tedavinin muhtemel riskleri ve yararları konusunda hastayı bilgilendirmeye yönelik olup, onun sağlıklı ve kendi açısından doğru bir karar vermesi amacına hizmet ettiğinden tıbbi müdahaleye verilen rızanın geçerlilik şartıdır ${ }^{66}$. Hekim aydınlatma yükümliüliiğünüü, küçüüün bireysel anlama ve kavrama kabiliyetini dikkate alarak yerine getirmelidir.

Tibbi müdahale konusunda karar verme hak ve yetkisine sahip olmamalarına rağmen, ayırt etme giicüne sahip küçügün ana babasına, tıbbi

\footnotetext{
${ }^{\infty} \mathrm{Bu}$ durumda küçüğŭ ayırt etme gücüne sahip olmadığı tıbbi müdahele yapıldıktan sonra ontaya çıksa dahi, yasal temsilcinin küçüğün yaranna olan tıbbi mỉdaheleyi reddetmesi yasal temsil yetkisinin aşıاması anlamına geldiłginden, bu irade dikkate alınmaz. Honsell/Wiegand. Artzrecht, s.173.

"H HY'nin 24'üncü maddesine göre, "yasal tensilciden veya -yasal temsilcinin izin vermemesi durumunda- mahkemeden izin almmast zaman gerektirecek ve hastaya derial müdahele edilmediği takdirde hayat veya hayati organlarndan birisi tehdit alma girecek ise izin şartt aranmaz. Yine ayn maddeye göre. "hayatt ve hayati organlardan birisini tehdit eden acil haller haricinde, rizanin her zaman geri almmast mümkindïr. Riáanu müdahale başladiktan sonra geri alınmasi, ancak abbi yönden sakinca bulunmaması şartuna bağlidir".

Bununla beraber. hastanın tedaviyi reddetmesi durumunda, hastanın kendisi hakkında karar verme hakkına saygı ilkesi ile yaşamın kutsallığı ilkesinden hangisine üstünlük tanınması gerektiğ hususu, doktrinde yoğun tartışmalara yol açmaktadır. Bkz. örneğin, Laufs/Uhlenbruck, \$52. Nr.12: Eibach, U. / Schaefer, K.: Patientenautonomie and Patientenwünsche, MedR 2001, s.21 vd

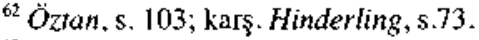

${ }^{63}$ Wolk, s.89.

${ }^{\text {t4 }}$ Wölk, s.89.

${ }^{65}$ Honsell/Wiegand, Arztrecht, s. 157; Naegeli, s. 114; Wölk, s.88.

* Ösunay, s.32; Çlingiroğlu, s.57; Şenocak, s. 44; Ayan, s.71; Aşgıłlu. C.: Tıbbi Yardim ve El Atmalardan Doğan Sorumilukiar, Ankara 1993, s.27; Honsell/Wiegand, Aratrecht. s.119: Deutsch, Nr. 100
} 
müdahale konusunda bilgi alma hakkı tanınmalıdır ${ }^{67}$. Bu hakkın tanınması, onların MK mad. 339 ve mad. 340 çerçevesinde çocugun bakımını, eğitimini ve kişiliğinin gelişimini sağlama hak ve ödevini gereği gibi yerine getirebilmeleri açısından zorunludur. Tibbi muidahale hakkında bilgi alma hakkı ana babanın velayet hakkına dayanmaktadır. Tıbbi miidahaleye rızayı ayırt etme gücüne sahip küçüğün vermesi, onun sağlık sorunlarına ilişkin olarak iç ilişkide ana babasının etkisinden de uzaklaştırılması anlamına gelmemelidir. Küçự̆ün sağlık sorunlarına iljşkin olarak ana babasının tavsiye ve dayanılmasına ihtiyacı vardır ${ }^{68}$. Ana babantn çocuğa gerekli korumayı ve dayanışmayı sağlaması için ise (çocugun yararı aksini şart koşmadıkça, örney̧in ana baba tarafından çocuğa şiddet uygulanması ihtimali) hekim tarafından tıbbi müdahale hususunda bilgilendirilmeleri gerekir $^{69}$.

Nihayet, açıklamalarımızın doğrudan doğruya tedavi amacını taşıyan tıbbi müdahalelere ilişkin olduğunu belirtmek gerekir. ODASNHK ${ }^{70}$ mad. 5'e göre, on sekiz yaşını doldurmamış ve ayırt etme gücüne sahip olmayan kişilerden organ ve doku almması yasaktır. NPHK ${ }^{71}$ mad. 4/II'ye göre ise, sterilizasyon ameliyatı, tıbbi sakınca olmadığ takdirde ergin kişinin isteği üzerine yapilır. Yine, HHY mad. 35'e göre, ergin ve ayırt etme gücüne sahip olmayanlara, kendilerine faydası olmaksızın sırf tıbbi araştırma amacını güden tıbbi müdahaleler hiçbir surette tatbik edilemez. Bu kanun hükümlerinde yer alan ve kanımızca isabetli olan düzenlemelerde, söz konusu tıbbi müdahaleler açısından küçüklerin ayırt etme gücüne sahip olmadıklarından hareket edilmiştir. Bu çerçevede, bu türden özel tıbbi müdahalelerin küçüklere uygulanması, küçüğgün kendisinin veya yasal temsilcisinin bu hususta rızası olsa dahi mümkün değildir ${ }^{72}$.

${ }^{67}$ Wolk, s.84.

${ }^{68}$ Wölk, s.85

( Hekimin sır saklama yükümlülüğünden hareketle aksi görüşte, Naegeli, s. 114; Honsell/Wiegand, Arztrecht, s.158, dpn. 147.

2238 sayll Organ ve Doku Alınması, Saklanması ve Nakli Hakkındaki Kanun.

${ }^{71} 2827$ sayılı Nüfus Planlaması Hakkında Kanun.

${ }_{72}$ Buna karşılık NPHK mad. 5/I'e göre, Kanun'un caiz kıldığı durumlarda kürtaj, ayırt etme gücüne sahip küç̧ủklerde velisinin iznine, küçüğğe vasi atanmışsa vasinin nzası yanında sulh hakiminin izin vermesine bağlıdır. Bu hukuki düzenlemede, kürtaj için küçuğgün rzzașı ile yasal temsilcinin nzası (küçük vesayet altında ise, buna jlaveten sulh mahkemesinin izni) birlikte arandı̆̆ından, ayırt etme gücüne sahip küçügŭün kürtaj için yapılacak ttbbi müdahaleyi veto etme hakkı vardır. Dolayısıyla küçük, böyle bir tıbbi müdahalenin yapılmasını, nzasını vermemek suretiyle engelleyebilir. Buna karşıllı, küçüğün küırtajı istemesi yasal temsilcinin ise istememesi durumunda, yasal temsilcinin bu tıbbi müdaheleyi veto etmek hakk1 vardır. Kanımızca, sorumluluğunu yaşam boyu taşıyacak olduğu bir çocuğu dünyaya getirmek ya da getirmemek ayırt etme gücüne sahip küçügün kararına bırakılmalıdır. Bu açıdan, Kanun'un caiz kıldı ̌̆ durumlarda (gebeliğin onuncu haftası doluncaya kadar tamamen isteğe bağlı olarak; on haftayı aşkın gebeliklerde ise, gebeliğin annenin hayatını tehdit etmesi veya dołacak çocuk ve onu takip edecek nesiller için ağır maluliyetin söz konusu olması şartıyla) 


\section{SONUÇ}

Küçìğe yapılacak tıbbi müdahalelerde, hukuki niteliği vekalet sözleşmesi olan tedavi sözleşmesi ile tıbbi müdahaleye rıza konusunu birbirinden ayırarak ele almak gerekir. Ana babanın çocuklarının (küı̧ügüun) tedavisi için hekimle yaptığı sözleşme, üçüncỉ kişi, yani küçcúk yararma sözleşmedir. $\mathrm{Bu}$ sözleşmenin tarafları ana baba ve hekim olup, hekime ödenecek ücreti ödeme borcu da ana babaya aittir. Ayırt etme gücüne sahip küçük ise, tedavi sözleşmesini, kural olarak ancak yasal temsilcisinin izin veya icazetiyle yapabilir.

Vücut ve ruh bütünlüğü üzerinde tasarruf anlamına gelen tıbbi müdahaleye rıza kişiye sıkı sıkıya bağlı bir hak olup, bu hakkın kullanılması, MK mad. 16'ya göre sadece ayırt etme gücüne sahip olmayı gerektirir. Dolayısıyla, ayırt etme gücüne sahip küçük -doğrudan doğruya tedavi amaçlı bir tıbbi müdahale söz konusu olduğu sürece- bu hakkı bizzat kullanabilmelidir. Küçüğün ayırt etme gücüne sahip olmaması durumunda ise, bu hak yasal temsilcisi tarafından kullanılır. Bu çerçevede, TŞSTIK 'nun 70 'inci maddesi ile HHY'nin 24'üncỉ maddesinde yer alan ve küçüğe yapılacak tıbbi müdahaleleri yasal temsilcinin rızasına bağlı tutan düzenlemeler, sadece ayırt etme gücüne sahip olmayan küçüklere yapılacak tıbbi müdahalelere uygulanmalıdır.

Küçüğün ayırt etme gücüne sahip olup olmadığını değerlendirecek olan kişi, onunla bizzat tedavi ilişkisi içerisinde olan hekimdir. Bu değerlendirmede, küçüğün, aydınlatma yükümlülüğgü çerçevesinde verilen bilgileri anlayıp anlamadığı, bu bilgileri kendi değer anlayışı açısından değerlendirip değerlendiremediği ve davranışını edindiği kanaate göre belirleyip belirleyemediği hususları önem kazanmaktadır.

Rızanın geçerlilik şartı olan tıbbi aydınlatma yükümlülïğü, rızayı verecek olan ayırt etme guicüne sahip küçüğe karşı yerine getirilmelidir. Buna karşılık ana babaya da, çocuğun yararı aksini şart koşmadıkça, yapılacak tıbbi müdahale konusunda bilgi alma hakkı tanınmalıdır.

kürtajın yapılıp yapılmaması, sadece ayırt etme gücüne sahip küçüüiin rızasına bağlı tutulmalıdır. Ancak, daha öncede belirtildiği gibi, ayırt etme gücüne sahip küçük tarafından kürtaj için yapılacak tıbbi müdahele sözleşmesinin geçerłj olabilmesi için, yasal temsilcinin jzin veya icazetine gerek vardır. Yasal temsilcinin haksız yere izin ve icazet vermekten kaçınması durumuna iliş̧kin olarak bkz. yukarıda, dpn 56. 